\title{
SMART BRT ITERA Management: A Pilot Project of Indonesia's Inclusive Bus Campus System
}

\author{
Zenia F Saraswati ${ }^{1{ }^{*}}$, Goldie Melinda Wijayanti ${ }^{2}$, Goldie Melinda Wijayanti ${ }^{3}$, Denny Juanda \\ Puradimaja $^{4}$ \\ , Urban and Regional Planning Departement, Institut Teknologi Sumatera, Indonesia \\ ${ }^{3}$ Civil Engineering Departement, Institut Teknologi Sumatera, Indonesia \\ Institut Teknologi Sumatera, Indonesia \\ *corresponding author: zenia.saraswati@pwk.itera.ac.id
}

\section{Article Info}

Received:

15 March 2021

Accepted:

25 May 2021

Published:

1 June 2021

DOI:

https://doi.org/10.14710/j

sp.2021.11209

\begin{abstract}
Sustainable transportation service is not only about reducing exhaust emissions but about its impact on society. This work seeks to analyze the potential of ITERA Smart Bus Rapid Transit (Smart BRT ITERA) as a regional campus buses in creating the accessibility needed by the wider community, affordable in terms of tariffs, efficient and supporting economic development and reducing emissions and waste generated in the Institut Teknologi Sumatera (ITERA) in Lampung, Indonesia. As a commitment to sustainability by planning Smart BRT ITERA form of collaboration with the Ministry of Transportation of the Republic of Indonesia. ITERA, in this case, acts as the operator of 10 buses grants by the Ministry to serve this activity. It is hoped that this project can become a best practice for other universities in Indonesia
\end{abstract}

\section{Keyword:}

Bus Rapid Transit Planning, University Bus Management, Inclusive, Sustainable

\section{Introduction}

In recent years there has been a growing interest in the role played by universities concerning institutional policies promoting sustainable transportation. It is frequently argued that universities are ideal places to explore the impact of measures promoting healthier transportation habits. The sustainable motivation is why universities around the world are building sustainable campuses and promoting green initiatives in which transportation is a central issue, not only for the sustainability of the institutions' facilities but as having a dragging effect on the cities and towns where they are located. The significant effect is especially true for small cities where university campuses are essential employment and economic hubs [1].

Institut Teknologi Sumatera (ITERA) is a public university that has an area of $\mathbf{2 8 5}$ hectares which is located in Lampung Selatan Regency, Indonesia. It is the first institute built 
in Sumatra Island brought by Institut Teknologi Bandung (ITB) as an effort to provide an even distribution of quality education, especially on the island of Sumatra. Currently, ITERA has 35 educational programs under five majors. This institution has grown to have 9412 students, 386 lecturers, and 286 staff registered in the current academic year and projects to be increased in the future. As a state institution, ITERA attracts students from various provinces in Indonesia, especially students of Sumatra island who want to continue their education in the fields of science and technology. $78 \%$ of ITERA's students come from the provinces of Sumatra island, and 55\% of ITERA students come from Lampung Province. ITERA commits to become a green campus by becoming part of the GreenMetric UI program followed by all the leading campuses in Indonesia and various countries in the world.

Students and lecturers are still traveling however the student housing or other housing facilities in or near the campus. This small travel can create a significant amount of carbon emissions especially if done repeatedly and considering the amount of people that make the trips. Students tend to use private vehicles if they have a driving license and can afford the cost [1]. Others have indicated that reducing the price of public transportation is an incentive to promote the use of collective means of transportation like the bus [2]. One way to reduce these emissions is establishing bus lines that travel to the main campus [3]. This bus system would give the students, lecturer, and staff a new option to reach the campus, one that potentially reduces net ITERA commuter emissions. However, monetary cost, time, and speed have also been identified as key factors with a significant influence on modal choices.

Being one of the main activities, ITERA's role in managing transportation has a broad impact especially on the movement in Lampung Selatan and Kota Bandar Lampung. Currently, no transportation provides services around the campus, making commuting to the ITERA campus carried out using a variety of private vehicle options, regardless of the presence of the majority from around the campus. Like most cities in Indonesia, most trips in Lampung Selatan are by riding motorbikes. To demonstrate its commitment to sustainability, ITERA pays special attention to the development of sustainable transportation. This was done one of them is by planning ITERA Smart Bus Rapid Transit (Smart BRT ITERA).

This work discusses how the ITERA in particular and universities in general may contribute to sustainable mobility by improving internal infrastructure, in the sense of studying the demand and paying attention to the operational costs needed to provide these services For this purpose collecting primary data by means of a survey. We deliberately choose an online questionnaire for this work because of its ability to reach a wider respondent in relatively a short time. This paper describes Smart BRT ITERA as a part of sustainability and discussing about the effect it has on the inclusivity aspect.

\section{Research Method}

Providing Sustainability in transportation generally aims to create the accessibility needed by the wider community, is affordable in terms of tariffs, is efficient and supports economic development, and reduces emissions and waste generated [4]. Talking about sustainable transportation is not only about its impact on the environment but also about its impact on the affected communities. Being inclusive is one of the things needed to be completely sustainable.

Surely motorised traffic is recognisably a major source of air and noise pollution in cities [5]. According to the EEA, transport emissions accounted for around one quarter of 
the EU's total GHG emissions and road transport represented around $73 \%$ of the GHG emissions for the entire transport sector in 2016. But the subjection of city road to motorized traffic only is also means injustice to those who don't have the access to motorised vehicle. The role of public transportation is important to tackle this problem.[6]

To further implement the Smart BRT ITERA scheme, researchers must also know what the supporting variables are. also pay attention to the extent to which in implementing BT the people of Bandar Lampung and its surroundings will be interested in choosing Smart BRT ITERA as a priority mode of transportation. And in implementing it, will the operation be able to reach enthusiasts who want to switch from private vehicles to public transportation later

This research focuses on urban and suburban areas around the ITERA campus, namely the Jati Agung District, South Lampung Regency, and Bandar Lampung City, which are the objects of the study area. This research focused on two main discussions: characteristics of potential riders and operating costs. The characteristics of potential riders are discussed based on the following indicator a) the origin of travel destinations, b) departure time, c) the modal distribution, d) willingness to pay, e) willingness to walk, and f) willingness switch mode of transportation.

The information about the potential rider was gathered from an online survey that was sent to 1998 people, a combination of students, lecturers and the staff which also consist of outsourcing staff; out of the total ITERA population of 9412 people. Sample is taken while maintaining a 10: 1 ratio between students and staff. All the questionnaire questions are multiple-choice closed-ended questions and referred to travels made during the week. BRT planning team that sends questionnaires to each respondent by sending a message to the institutional email addresses with a link to the survey, in November 2019. "Online" surveys present added difficulties in their execution phase, as shown in the literature. Among the most frequent ones, we can mention technical problems or the fear of loss of confidentiality that prompts the respondent to leave the questionnaire incomplete or even unanswered [7]. Of the total number of responses received $78 \%$ came from students, $16 \%$ from lecturer, and $6 \%$ from staff.

On the other side, information about operational cost is calculated from the length of the route, the amount of trip per day, and the number of buses needed for the operation of Smart BRT ITERA. According to [8], basically, vehicle operating costs consist of fixed costs, and running costs, namely the costs that will exist if the vehicle operates. Transportation costs are part of the burden of production costs which will eventually become part of the price of certain production or services. Transportation costs are divided into 2 (two), namely internal costs consisting of direct costs and indirect costs as well as external costs studied in this study are health insurance costs.

For this study, the fixed operating cost is not not considered because the bus operated is a grant bus from the ministry. a on the length of the route and the number of rites that were taken, we were able to count for direct operational expenses which include: bus crew salaries, fuel costs, tire costs, small service fees, large service fees, overhaul costs, engine oil addition costs, bus washing costs, tax fees and eligibility tests as well as additional facility costs. We also count for the indirect expenses such as non-bus crew employees and their insurance. The data was gathered from the Smart BRT ITERA planning team. Then the tariff is calculated under the assumption of a $70 \%$ occupancy rate. 


\section{Case Study}

ITERA Smart BRT is a form of collaboration between ITERA and the Ministry of Transportation of the Republic of Indonesia. ITERA, in this case, acts as the operator of 10 buses grants by the Ministry to serve this activity. ITERA Smart BRT are using a small bus fleet with a capacity of 30 people whose interiors have been adapted to the needs of commuter trips. ITERA Smart BRT has 2 routes that are served: 1) ITERA - Way Kandis with route length of $12.13 \mathrm{~km}$ with 18 stops; and 2) ITERA - UIN with route length of 10,29 km 8 stops. Smart BRT ITERA is expected to serve trips of students, lecturers, and staff of ITERA starting from 05.00 to 20.00 every day. There are currently no clear bus stops and signs for bus stops for ITERA Smart BRT.
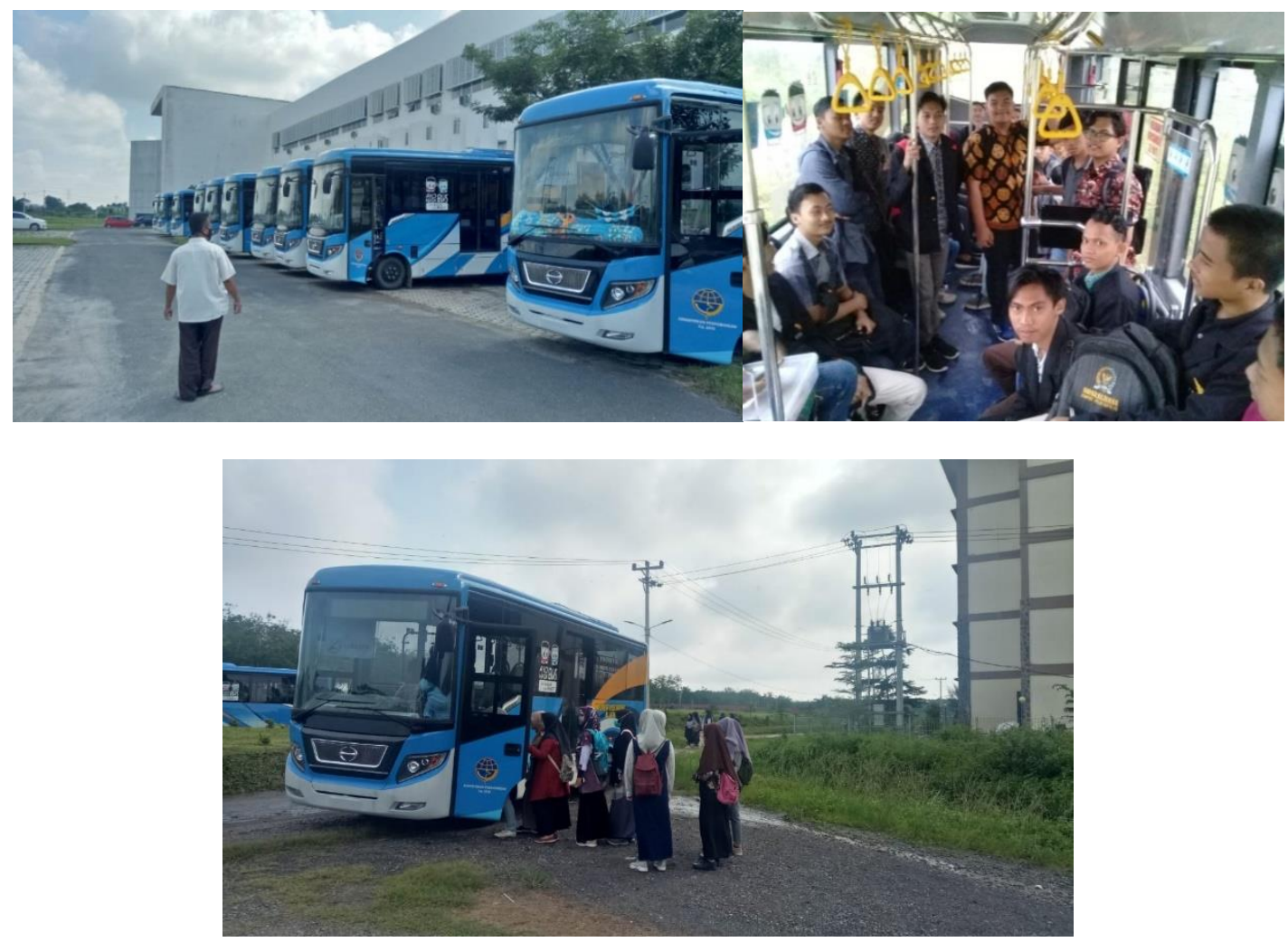

Figure 1. Smart BRT ITERA (source: Smart BRT ITERA planning team)

The planned range of Smart BRT ITERA services can be seen in Figure 2. Route 1 includes, ITERA - Way Kandis (green): Jalan Terusan Ryacudu - Jalan Pangeran Suhaimi Jalan Airan Raya - Jalan Ratu Dibalau - Jalan Lintas Sumatera - Jalan Ryacudu - Jalan Pangeran Suhaimi - Jalan Terusan Ryacudu; and for Route 2 includes, ITERA - UIN (orange): Jalan Terusan Ryacudu - Jalan Pangeran Suhaimi - Jalan ryacudu - Jalan Sultan Agung - Jalan Letjen Alamsyah Ratu Prawiranegara - Jalan Urip Sumoharjo - Jalan Endro Suratmin - Jalan Pangeran Senopati Raya - Jalan terusan Ryacudu.

The rate issued for trips using the Smart BRT ITERA is IDR 1,700. - IDR 2,000 flat for every ride. This payment is expected to be done using electronic payment systems. This could be formed as Emoney system or Student's ID Electronic Card integrated with the campus. This system application is believed needed as to precisely provide time information for passengers for the future to help the evaluation and planning process in the future. 


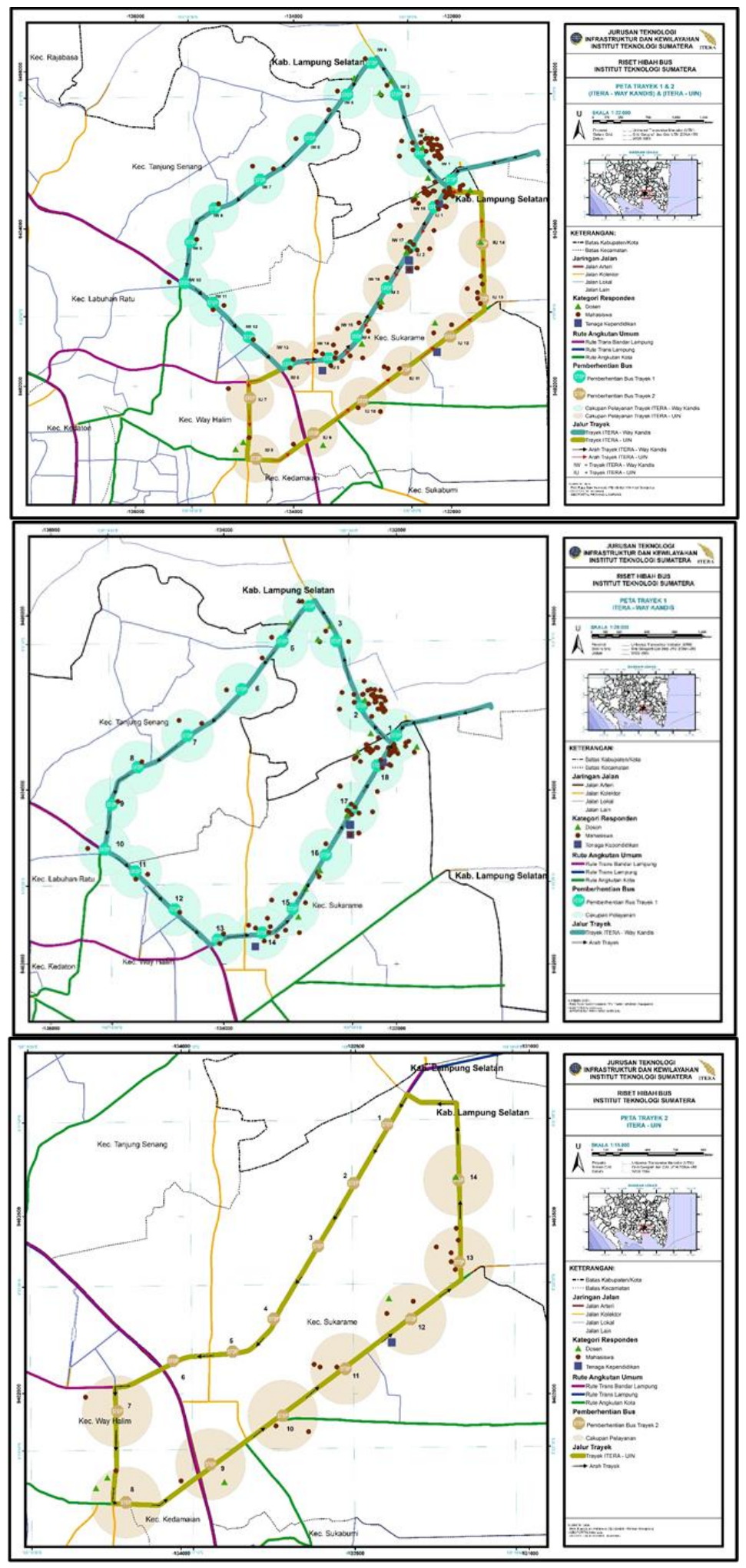

Figure 2. Smart BRT ITERA route planning map (source: Smart BRT ITERA planning team)

\section{Result}

The The variety of the ITERA's students origins has caused the scattered-plot housing of academics civitas (students, lecturers and staff) of ITERA around campuses such as 
ITERA's boarding house, Jati Agung district of South Lampung, and peri-urban area of Bandar Lampung city. Based on the map of the pattern of respondents' movements, the origin of commuter trips to ITERA has the most densely populated cluster around Jati AgungSukarame making daily trips at most distances less than $3 \mathrm{~km}$. Whereas in other areas other distributions are in other administrative regions. The data showed how $83.6 \%$ of the pkm were traveled within the urban area, with the remaining $16.4 \%$ corresponded to inter-urban or peri-urban travels. While lecturers and staff' origin is relatively spread out in the city, the origin of the students is significantly centred in Jati Agung district of South Lampung.

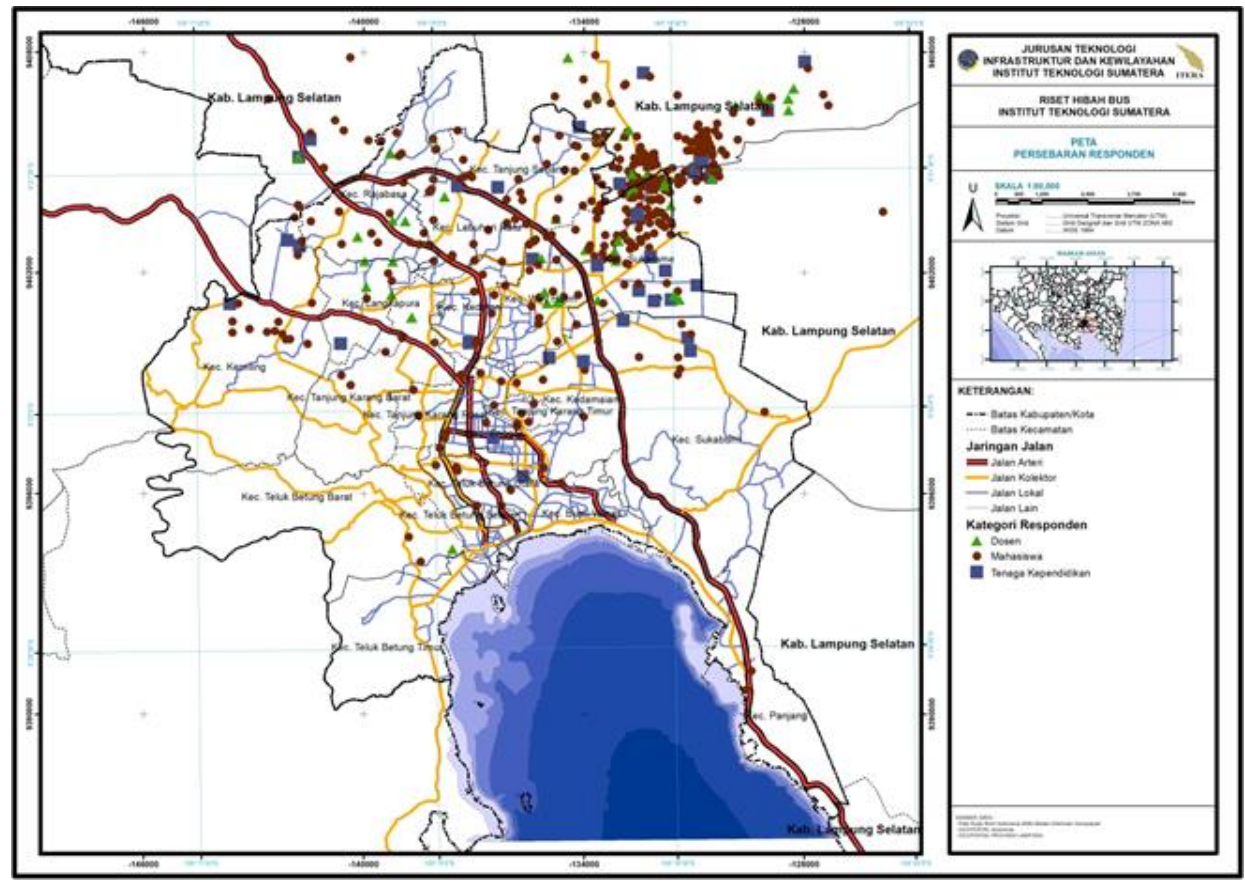

Fig 3. the origin of travel destinations map (source: Smart BRT ITERA planning team)

The travel mode most often used to commute to the ITERA was private motorcycle by a significant margin, followed by ride shared motorcycle and riding the public transport (54\%, $29 \%$ and $12 \%$ of the respondent) (Fig. 3). On the contrary, driving cars were the least used modes (4\%). In addition, $99 \%$ of the total number of commutes to the ITERA were unimodal. Given the difference in schedules for students, the depart and return trip have more spread out in timelines. However, most of the travel still follows the rush hours with the journey departing at 6:00 to 8:00, and the return trip, but the return trip is still mostly done at 17.00-18.00.

About the response to the bus service, based on the data obtained, the respondent wishes to switch modes on the mode currently in use reached $65 \%$. Besides, respondents were also asked about their preferences regarding services considered for choosing Smart BRT ITERA as an alternative to transportation is very appropriate when compared to the use of their old modes. Up to $24 \%$ of the commuters are willing to walk $500-1000 \mathrm{~m}$ in the first/last stage of their travel (approx. $10 \mathrm{~min}$ ). The rest walk for $<5$ mins within the campus in the first/final stage of their journey. Prospective users tend to have the desire to pay below Rp. 1000 / km (68\%) with the majority only willing to pay less than IDR $500 / \mathrm{km}$ (42\%). In the context of bus routes, the desire to pay can be interpreted as IDR 6000 for one round of route 1 and IDR 5000 for one round of route 2 . Because of the circular route, the longest distance given by this route is only half the maximum. 


\section{Discussion}

Moving The background for the procurement of ITERA Smart BRT is ITERA's effort to become a more sustainable institution. Using public transit to commute for students and staff has the potential to reduce $\mathrm{CO}_{2}$ emissions and traffic congestion. Setting up new transit routes can be achieved at a relatively low cost if current / past buses can be repurposed, also possible to achieve in a relatively short time frame given existing processes and training infrastructure on the main campus. Given a high enough demand, ITERA can benefit from this program.

However, the use of buses is not only beneficial for reducing $\mathrm{CO}_{2}$ emissions due to reduced congestion. With the domicile of origin of ITERA students who come from far away, it gives them disadvantage to ownership of motorized vehicles. ITERA Smart BRT bus service provides more opportunities for accessibility for students without access to motorized vehicles. This will provide an opportunity for other types of public transportation to develop especially those to offer accessibility wider to the whole city dweller.

This demand is still very vulnerable to Smart BRT ITERA. It can be seen from the willingness to pay that is only less than IDR 500, making most trips under $4 \mathrm{~km}$, has a maximum willingness to pay the value of IDR 2000. At the same time, the value of return on investment can still be fulfilled even with a tariff of IDR 2000. However, this depends on the occupancy rate of $70 \%$, which is very large, even for buses that have been operating for a long time [9]. Even though bus ridership among commuting trips to and from campus, Smart BRT ITERA is not only proclaimed as campus shuttles.

On the other hand, the threat that is owned by the bus is ride shared motorcycles. With a service that provides a headway of 45 minutes, travelling under $4 \mathrm{~km}$ makes little sense to take a bus. Especially considering the large share of prospective passengers already owning motorbikes and using motorbikes as their daily vehicles, this headway is a significant obstacle to attracting new bus users. It also cannot be forgotten that the Smart BRT ITERA does not reach all the distribution origin of commuter trips but only a large portion of the students that mostly use motorcycles for their daily travel.

\section{Concluding Remarks}

The development of a sustainable transportation system is, of course, a goal that every university must achieve. The management of ITERA Smart Bus Rapid Transit (Smart BRT ITERA) As a commitment to sustainability is currently in a developing phase, of course, it will experience many challenges in its journey. However, as part of a wider society, this program is like all of ITERA's each other treatments demonstrates its responsibility to students, educators and staff, as well as the community. ITERA constant concern is in the quality of education, and will be keeping up efforts for that.

\section{References}

1. Delmelle, E. M., \& Delmelle, E. C. (2012). Exploring spatio-temporal commuting patterns in a university environment. Transport Policy, 21, 1-9. doi:10.1016/j.tranpol.2011.12.007

2. Hancock, L., \& Nuttman, S. (2014). Engaging higher education institutions in the challenge of sustainability: Sustainable transport as a catalyst for action. Journal of Cleaner Production, 62, 62-71. doi:10.1016/j.jclepro.2013.07.062

3. Pérez-Neira, D., Rodríguez-Fernández, M. P., \& Hidalgo-González, C. (2020). The greenhouse gas mitigation potential of university commuting: A case study of the 
University of León (Spain). Journal of Transport Geography, 82, 102550. doi:10.1016/j.jtrangeo.2019.102550

4. Litman, T. (2007). Developing Indicators for Comprehensive and Sustainable Transport Planning. Transportation Research Record: Journal of the Transportation Research Board, 2017(1), 10-15. doi:10.3141/2017-02

5. Batty, P., Palacin, R., \& González-Gil, A. (2015). Challenges and opportunities in developing urban modal shift. Travel Behaviour and Society, 2(2), 109-123. doi:10.1016/j.tbs.2014.12.001

6. An, R., Shen, J., Ying, B., Tainio, M., Andersen, Z. J., \& Nazelle, A. D. (2019). Impact of ambient air pollution on physical activity and sedentary behavior in China: A systematic review. Environmental Research, 176, 108545. doi:10.1016/j.envres.2019.108545

7. Tourangeau, R., Conrad, F. G., \& Couper, M. P. (2013). Sampling and Coverage Issues for Web Surveys. The Science of Web Surveys, 11-35. doi:10.1093/acprof:oso/9780199747047.003.0002

8. Rodrigue, J. (2020). The geography of transport systems. Abingdon, Oxon: Routledge.

9. Qohar, M. T. (2018). Analisis Implementasi Kebijakan Terminal Parkir Elektronik Di Kota Bandung. Jurnal Wacana Kinerja: Kajian Praktis-Akademis Kinerja Dan Administrasi Pelayanan Publik, 21(2), 37. doi:10.31845/jwk.v21i2.108 